\title{
A Simple Method of Evaluating the Thermal Properties of Metallurgical Cokes under High Temperature
}

\author{
Guangzhi Yang *(D), Xiaoqiang Wang (D), Ting Shi, Xinci Wu and Yuhua Xue * \\ School of Materials Science and Engineering, University of Shanghai for Science and Technology, \\ Shanghai 200093, China; XQ320557@163.com (X.W.); shiting_usst@163.com (T.S.);wxc561@163.com (X.W.) \\ * Correspondence: yanggzh@usst.edu.cn (G.Y.); xueyuhua@usst.edu.cn (Y.X.); Tel.: +86-21-55270632 (G.Y.)
}

check for updates

Citation: Yang, G.; Wang, X.; Shi, T.; $\mathrm{Wu}, \mathrm{X}$.; Xue, Y. A Simple Method of Evaluating the Thermal Properties of Metallurgical Cokes under High Temperature. Materials 2021, 14, 5767. https://doi.org/10.3390/ma14195767

Academic Editor: Frank Czerwinski

Received: 7 September 2021

Accepted: 30 September 2021

Published: 2 October 2021

Publisher's Note: MDPI stays neutral with regard to jurisdictional claims in published maps and institutional affiliations.

Copyright: (c) 2021 by the authors. Licensee MDPI, Basel, Switzerland. This article is an open access article distributed under the terms and conditions of the Creative Commons Attribution (CC BY) license (https:// creativecommons.org/licenses/by/ $4.0 /)$.

\begin{abstract}
The reactivity index of weight loss (RI) and tumbling strength after the reaction $\left(\mathrm{I}_{10}{ }^{600}\right.$ ) of manufacturing coke were first tested at a temperature series of 1100,1200 , and $1300{ }^{\circ} \mathrm{C}$ under $\mathrm{CO}_{2}$ atmosphere with different compositions and duration times to study the effects of temperature, time, and gas composition on coke hot strength. Then the RI/ $\mathrm{I}_{10}{ }^{600}$, carbon structure, and optical texture of the cokes prepared from different single coals were mainly studied after a solution reaction with $\mathrm{CO}_{2}$ under a high temperature of $1300{ }^{\circ} \mathrm{C}$ and a standard temperature of $1100{ }^{\circ} \mathrm{C}$. It was found that temperature greatly affects the RI/ $\mathrm{I}_{10}{ }^{600}$ of coke, especially at high temperatures up to $1300{ }^{\circ} \mathrm{C}$. Compared with standard tests under $1100{ }^{\circ} \mathrm{C}$, the changes of $\mathrm{RI} / \mathrm{I}_{10}{ }^{600}$ for different cokes are very different at $1300{ }^{\circ} \mathrm{C}$, and the changes are greatly related to coke optical texture. Under a high temperature in the testing method, the tumbling strength of cokes with more isotropy increased, whereas it decreased for those with less isotropy. This simple method of using high temperature could yield the same results when compared with complicated simulated blast furnace conditions.
\end{abstract}

Keywords: coke; tumbling strength; reactivity index; optical texture

\section{Introduction}

Coke is a basic, essential, and irreplaceable raw material for blast furnace (BF) ironmaking, in which it plays four major roles, namely reductant, carbon source, fuel, and frame support. It is very important to use cokes with appropriate reactivity and high strength for the stable running of a BF. The reactivity and strength of coke are often evaluated by reactivity index (CRI) and strength after reaction (CSR) in a standard testing method. CRI is determined by exposing coke to pure carbon dioxide for solution reaction at $1100{ }^{\circ} \mathrm{C}$ for $2 \mathrm{~h}$ and measuring the coke weight loss afterward. CSR is determined by weighing the ratio of reacted coke with $+10 \mathrm{~mm}$ sizes after being tumbled for 600 revolutions in an I-drum. CRI/CSR is widely used to evaluate the quality of coke by steel industries around the world. Many factors that affect the CRI/CSR values of coke have been studied, including mineral composition, reflectance parameters, porous structure, and optical texture [1-4].

However, the reaction condition of standard tests is different from the actual experiences of coke in BFs. At first, the actual reaction temperature in the $\mathrm{BF}$ ranges from $800{ }^{\circ} \mathrm{C}$ to $1400{ }^{\circ} \mathrm{C}$. Secondly, the reaction gas of $\mathrm{CO}_{2}$ is not pure and its composition changes with the descent of coke from top to bottom in the BF. Finally, the reaction time lasts longer than $2 \mathrm{~h}$. Thus, evaluating the accuracy of CRI/CSR for coke quality in BFs has been disputed for a long time, especially in recent years since some researchers have found that the coke quality of CRI/CSR is not in good accordance with BF practices or experimental BF conditions. Many researchers have revised the CRI and CSR test conditions, including changing the pure $\mathrm{CO}_{2}$ to a mixture, raising the reaction temperature to a higher temperature, controlling for a constant weight loss of coke, etc. Most found a poor correlation between the results of simulated conditions and standard conditions, or even a mistake in the estimation of coke quality by CRI/CSR. They proposed that the postreaction strength test should be modified in accordance with the individual BF operation, especially at high temperatures [5-14]. 
In our former publication [15], we reported our revised simulated conditions for coke evaluation at high temperature. The reaction temperature was up to $1350{ }^{\circ} \mathrm{C}$ and the total reaction time was about $334 \mathrm{~min}$. We found that changes in the strength of coke after a reaction are very different for different cokes. Under simulated conditions compared with standard methods of CRI/CSR, some cokes have higher strengths while others have lower ones, leading to a big difference in evaluating coke strength under different conditions.

In the following study, we investigated more samples in our laboratory and found the same results, which further confirms that the standard NSC method does have some limitations in simulating coke degradation behavior in BFs and evaluating the thermal properties of coke.

Since the actual operating conditions of a BF are complicated and it is difficult to identically replicated these conditions in simulation, different scholars have their own understandings about the simulations. The experimental conditions are all complicated compared with the standard NSC method, and even special equipment is required.

In this paper, a simple method of testing coke under high temperature conditions is proposed to replace the complicated simulation methods. We hope to provide a simple method with a better result compared with the standard NSC method. Because high temperature accelerates the rate of coke solution loss reaction and causes the tumbling strength of coke decrease quickly, the proper conditions were first investigated by studying metallurgical coke from blended coals. Then, eight cokes from single coals of different volatiles were tested. The changes in tumbling strength, carbon structure, and optical texture of the cokes were then studied. Afterward, the main differences in the changes were compared, and the possible reasons for the differences were proposed.

\section{Materials and Methods}

\subsection{Samples}

Samples of one metallurgical coke from blended coals and pilot oven cokes from single coals of different volatiles were studied here. All the cokes were provided by Baosteel Company in China. The proximate analyses of the blended and single coal samples for the cokes are shown in Table 1. Among them, C1 is blended coal for metallurgical coke and the others are single coals for pilot oven cokes with different volatiles. $\mathrm{C} 1$ was coked in a manufacturing coke oven and those of $\mathrm{C} 2-\mathrm{C} 9$ were coked in a $70 \mathrm{~kg}$ pilot oven.

Table 1. Proximate analyses of the coals.

\begin{tabular}{cccccccccc}
\hline Items & C1 & C2 & C3 & C4 & C5 & C6 & C7 & C8 & C9 \\
\hline Moisture, \% & 8.68 & 9.78 & 9.90 & 9.20 & 11.05 & 9.60 & 7.30 & 9.72 & 8.20 \\
Fixed carbon, \% & 64.63 & 69.94 & 68.96 & 61.42 & 65.14 & 69.72 & 57.20 & 57.01 & 57.55 \\
Ash, \% & 8.96 & 9.98 & 10.03 & 9.13 & 9.94 & 9.45 & 7.93 & 8.06 & 7.58 \\
Volatile, \% & 26.41 & 20.08 & 21.01 & 29.45 & 24.93 & 20.81 & 34.86 & 34.93 & 34.87 \\
G & 84.00 & 90.75 & 86.00 & 90.00 & 90.50 & 75.43 & 80.60 & 79.80 & 78.70 \\
Y, mm & 14.00 & 14.50 & 11.00 & 23.00 & 23.75 & 10.14 & 11.40 & 13.00 & 13.33 \\
A + B, \% & 43.50 & 81.25 & 58.00 & 176.00 & 113.50 & 11.71 & 29.80 & 39.00 & 122.50 \\
\hline
\end{tabular}

\subsection{Solution Reaction Tests and Characterization}

Coke samples were subjected to a series of reaction conditions, including the standard test and others with different high temperature and $\mathrm{CO}_{2}$ content. The standard test involves reacting $200 \mathrm{~g}$ of $23-25 \mathrm{~mm}$ coke particles at $1100{ }^{\circ} \mathrm{C}$ with $100 \% \mathrm{CO}_{2}$ for $2 \mathrm{~h}$ according to the Chinese standard f GB/T 4000-2008, and the others were conducted with a gas mixture of $\mathrm{CO}_{2}$ and $\mathrm{N}_{2}$ under different temperatures and duration times. For all the tests, the flowing rate of total gases was $5 \mathrm{~L} / \mathrm{min}$. The reaction index of the weight loss percentage (RI) and tumbling strength after reaction $\left(\mathrm{I}_{10}{ }^{600}\right)$ were tested according to the standard method.

The surface morphology was observed by scanning electron microscopy (SEM) (The Dutch FEI)) with an accelerating voltage of $20 \mathrm{kV}$. X-ray diffraction was performed on an ESCALAB 250Xi (Bruker, Germany) with Al Ka X-ray radiation as the X-ray source 
for excitation. The optical texture was examined on polished surfaces using a ZEISS Imager M1m optical microscope. The optical texture of coke was classified by isotropy and anisotropy.

\section{Results and Discussion}

\section{1. $R I / I_{10}{ }^{600}$ of Metallurgical Coke under Different Reaction Conditions}

Table 2 shows the testing conditions and $\mathrm{RI} / \mathrm{I}_{10}{ }^{600}$ results of metallurgical coke $\mathrm{C} 1$ after reaction with $\mathrm{CO}_{2}$. T1 is the standard test and the $\mathrm{RI} / \mathrm{I}_{10}{ }^{600}$ under $\mathrm{T} 1$ is equal to CRI/CSR. In theory, the chemical reaction of coke and $\mathrm{CO}_{2}$ follows the relation of Equation (1), that is, $1 \mathrm{~mol}$ of $\mathrm{C}$ atoms needs $1 \mathrm{~mol}$ of $\mathrm{CO}_{2}$ to finish the reaction. With the assumption of coke being composed of $100 \%$ carbon, it may be approximately calculated that every $12 \mathrm{~g}$ coke by weight needs $22.4 \mathrm{~L} \mathrm{CO}_{2}$ by volume. Table 2 also gives the total amount of $\mathrm{CO}_{2}$ fed, the reaction amount of $\mathrm{CO}_{2}$, and the reaction ratio of $\mathrm{CO}_{2}$. The reaction amount is calculated through $200 \mathrm{~g}$ coke multiplied by reactivity, divided by $12 \mathrm{~g}$, and multiplied by $22.4 \mathrm{~L}$. The reaction ratio of $\mathrm{CO}_{2}$ refers to the reaction amount divided by the amount fed. It can be seen that the RI values were $24.7 \%, 19.3 \%$, and $12.9 \%$ respectively, from $\mathrm{T} 1, \mathrm{~T} 2$, and $\mathrm{T} 3$ with the $\mathrm{CO}_{2}$ concentration reducing by half sequentially under the same duration time and temperature. Compared with T1, the RI values of T2 and T3 did not decrease by half sequentially and were far higher than the values calculated by half $(12.35 \%$ and $6.175 \%$ ). The reason is that the reaction ratio of $\mathrm{CO}_{2}$ increased from $15.4 \%$ to $24.0 \%$ and $32.2 \%$. With the decrease in $\mathrm{CO}_{2}$ content, the reaction ratio of $\mathrm{CO}_{2}$ is increased because the chemical reaction is controlled by diffusion to some extent, and less $\mathrm{CO}_{2}$ was released without reaction under low composition. It can also be seen that by comparing T2 with T4 and $\mathrm{T} 1$ with $\mathrm{T} 5$ under the same $\mathrm{CO}_{2}$ content, with the increase in temperature and decrease in duration time, tiny differences existed for the RI values, but the reaction ratio of $\mathrm{CO}_{2}$ increased greatly. It can be noted that with the increasing temperature, the reaction rate accelerates and the reaction ratio of $\mathrm{CO}_{2}$ increases.

$$
\mathrm{C}+\mathrm{CO}_{2}=2 \mathrm{CO}
$$

Table 2. Test conditions and $\mathrm{RI} / \mathrm{I}_{10}{ }^{600}$ results of metallurgical coke $\mathrm{C} 1$.

\begin{tabular}{|c|c|c|c|c|c|c|c|c|}
\hline \multirow[b]{2}{*}{ Test } & \multicolumn{4}{|c|}{ Test Conditions } & \multicolumn{4}{|c|}{$\mathrm{C} 1$} \\
\hline & $\begin{array}{c}\text { Temperature } \\
\left({ }^{\circ} \mathrm{C}\right)\end{array}$ & $\begin{array}{l}\text { Time } \\
\text { (h) }\end{array}$ & $\mathrm{CO}_{2}(\%)$ & $\begin{array}{l}\text { Total Amount of } \\
\mathrm{CO}_{2} \text { Fed (L) }\end{array}$ & $\begin{array}{c}\text { RI } \\
(\%)\end{array}$ & $I_{10} 600(\%)$ & $\begin{array}{c}\text { Reaction } \\
\text { Amount of } \\
\mathrm{CO}_{2}(\mathrm{~L})\end{array}$ & $\begin{array}{l}\text { Reaction } \\
\text { Ratio of } \\
\mathrm{CO}_{2}(\%)\end{array}$ \\
\hline $\mathrm{T} 1^{\mathrm{a}}$ & 1100 & 2 & $100 \%$ & 600 & 24.7 & 68.6 & 92.2 & 15.4 \\
\hline $\mathrm{T} 2$ & 1100 & 2 & $50 \%$ & 300 & 19.3 & 72.7 & 72.0 & 24.0 \\
\hline T3 & 1100 & 2 & $25 \%$ & 150 & 12.9 & 78.4 & 48.2 & 32.2 \\
\hline $\mathrm{T} 4$ & 1200 & 1 & $50 \%$ & 150 & 18.1 & 71.0 & 67.6 & 45.0 \\
\hline $\mathrm{T} 5$ & 1300 & 0.5 & $100 \%$ & 150 & 23.3 & 68.1 & 87.0 & 58.0 \\
\hline
\end{tabular}

${ }^{\mathrm{a}} \mathrm{T} 1$ is the standard test.

Furthermore, the reaction tests of $\mathrm{T} 1$ and $\mathrm{T} 5$ contain the same $\mathrm{CO}_{2}$ concentration of $100 \% \mathrm{CO}_{2}$ but different temperatures $\left(1100^{\circ} \mathrm{C}\right.$ and $\left.1300{ }^{\circ} \mathrm{C}\right)$ and duration times $(2 \mathrm{~h}$ and $0.5 \mathrm{~h}$ ). The time difference is $4 \times$ and the temperature is $200^{\circ} \mathrm{C}$, but the $\mathrm{I}_{10}{ }^{600}$ results are nearly the same of $68.6 \%$ and $68.1 \%$. At the same time, according to the comparison of $\mathrm{T} 2$ and T4, the time difference is 2 and temperature is $100{ }^{\circ} \mathrm{C}$, but the $\mathrm{I}_{10}{ }^{600}$ results are also nearly the same of $72.7 \%$ and $71.0 \%$.

It can be concluded that temperature, gas composition, and reaction time all affect solution reaction and tumbling strength of coke. It may be presumed that the influence of increased temperature on tumbling strength for metallurgical coke $\mathrm{C} 1$ from a standard test of $1100^{\circ} \mathrm{C}$ can be offset by reducing duration time with the relation of every $100{ }^{\circ} \mathrm{C}$ by half time. 


\section{2. $\mathrm{RI} / \mathrm{I}_{10}{ }^{600}$ of Pilot Cokes from Single Coals under High Temperature and Standard Conditions}

Because little change was found in the tumbling strength for metallurgical coke $\mathrm{C} 1$ under T1 of the standard test and T5 of high temperature, more samples of cokes from single coals were tested to further study the change relations. The results are shown in Table 3.

Table 3. The results of $\mathrm{RI} / \mathrm{I}_{10}{ }^{600}(\% / \%)$ for pilot cokes from single coals under high temperature and standard conditions.

\begin{tabular}{ccccccccc}
\hline Test & C2 & C3 & C4 & C5 & C6 & C7 & C8 & C9 \\
\hline T1 $^{\text {a }}$ (CRI/CSR) & $14.3 / 77.5$ & $24.8 / 62.6$ & $25.5 / 57.3$ & $41.0 / 45.7$ & $28.2 / 45.1$ & $46.3 / 32.3$ & $49.5 / 25.5$ & $66.2 / 14.7$ \\
$\mathrm{~T}\left(\mathrm{RI} / \mathrm{I}_{10}{ }^{600}\right)$ & $19.3 / 66.7$ & $26.0 / 59.6$ & $28.6 / 58.4$ & $29.7 / 65.9$ & $28.4 / 46.0$ & $31.4 / 63.8$ & $34.4 / 63.7$ & $34.3 / 65.1$ \\
(I $\left._{10}{ }^{600}-\mathrm{CSR}\right)$ & $-10.8 \%$ & $-3 \%$ & $1.1 \%$ & $20.2 \%$ & $0.9 \%$ & $31.5 \%$ & $38.2 \%$ & $50.4 \%$ \\
\hline
\end{tabular}

a The $\mathrm{RI} / \mathrm{I}_{10}{ }^{600}$ of $\mathrm{T} 1$ is CRI/CSR.

It can be seen that the $\mathrm{RI} / \mathrm{I}_{10}{ }^{600}$ change results of cokes from single coals under high temperature of $\mathrm{T} 5$ are very different. The $\mathrm{I}_{10}{ }^{600}$ values may be smaller, larger, or similar compared to their CSR under the standard condition. For C2 and C3, the $\mathrm{I}_{10}{ }^{600}$ are smaller than their CSR, while for C5, C7, C8, and C9, the $\mathrm{I}_{10}{ }^{600}$ is larger, and for C4 and C6, the $\mathrm{I}_{10}{ }^{600}$ values are almost the same. The $\mathrm{I}_{10}{ }^{600}$ of $\mathrm{C} 2$ and $\mathrm{C} 3$ decreases moderately to $66.7 \%$ and $59.6 \%$ from $77.5 \%$ and $62.6 \%$. The values of $\left(\mathrm{I}_{10}{ }^{600}-\mathrm{CSR}\right)$ are $-10.8 \%$ and $-3 \%$, respectively. While the $\mathrm{I}_{10}{ }^{600}$ of $\mathrm{C} 5, \mathrm{C} 7, \mathrm{C} 8$, and $\mathrm{C} 9$ increases greatly to $65.9 \%, 63.8 \%, 63.7 \%$, and $65.1 \%$ from $45.7 \%, 32.3 \%, 25.5 \%$, and $14.7 \%$, the values of $\left(\mathrm{I}_{10}{ }^{600}\right.$-CSR) are $20.2 \%, 31.5 \%, 38.2 \%$, and $50.4 \%$, respectively. The $\mathrm{I}_{10}{ }^{600}$ of $\mathrm{C} 4$ and $\mathrm{C} 6$ changes slightly to $58.4 \%$ and $46.0 \%$ from $57.3 \%$ and $45.1 \%$ and the values of $\left(\mathrm{I}_{10}{ }^{600}-\mathrm{CSR}\right)$ are $1.1 \%$ and $0.9 \%$ respectively, which can be considered as no significant changes occurring.

As mentioned above, the influence of reaction temperature on tumbling strength of metallurgical $\mathrm{C} 1$ from a standard test can be offset by time with the relation of every $100{ }^{\circ} \mathrm{C}$ by half time; that is, the tumbling strength values of $\mathrm{C} 1$ under $\mathrm{T} 1$ and $\mathrm{T} 5$ were of a similar range. However, this seems to be inapplicable for different cokes from single coals here.

The comparison between $\mathrm{I}_{10}{ }^{600}$ (red data) under T5 with CSR $\left(\mathrm{I}_{10}{ }^{600}\right.$ under T1, black data) is shown in Figure 1. It can be seen that the $\mathrm{I}_{10}{ }^{600}$ changes under high temperature are very different. Generally, the $\mathrm{I}_{10}{ }^{600}$ values for low CSR cokes $(\mathrm{C} 7, \mathrm{C} 8$, and C9) increase from conditions of T1 to T5. The lower the CSR, the higher the amount will increase. With the increase in CSR, the increasing amount of $\mathrm{I}_{10}{ }^{600}$ becomes smaller and smaller until it disappears. Some decreases may even occur for high CSR cokes (C2 and C3).

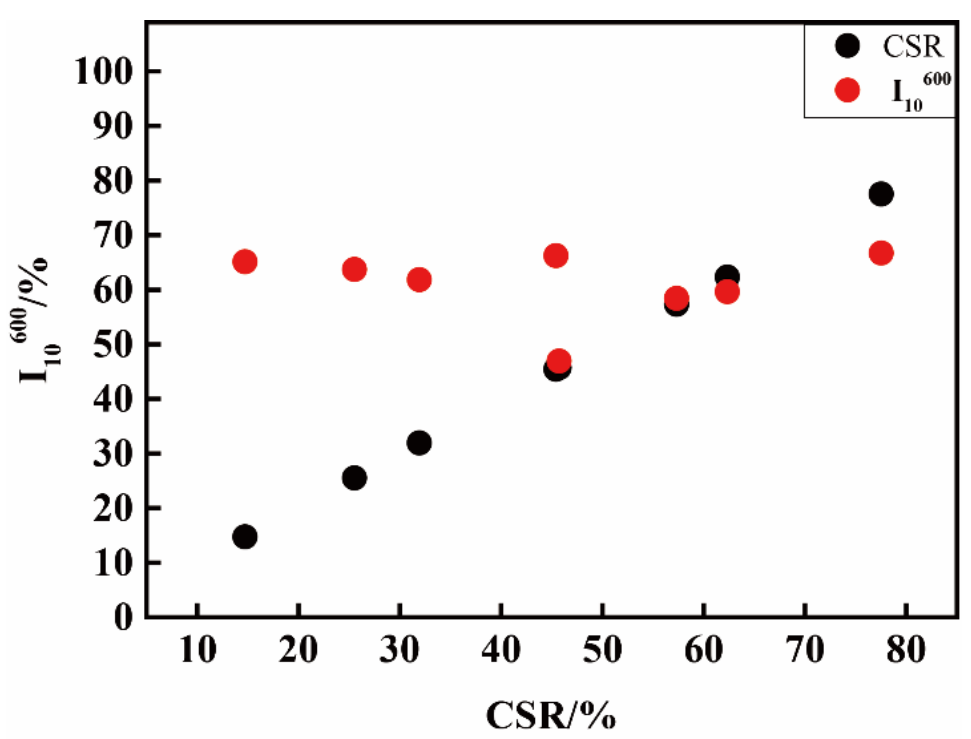

Figure 1. The comparison of $\mathrm{I}_{10}{ }^{600}$ under $\mathrm{T} 5$ with CSR under T1 of cokes from single coals. 
On the other hand, after reacting with $\mathrm{CO}_{2}$ at a low temperature of $1100{ }^{\circ} \mathrm{C}$, cokes from different volatile coals have big differences in tumbling strength. While at a high temperature of $1300{ }^{\circ} \mathrm{C}$, the differences shrink, and sometimes a reversion even appears (for red data, some left values of $\mathrm{I}_{10}{ }^{600}$ with low CSR are larger than those of the right ones).

Furthermore, the values of $\mathrm{I}_{10}{ }^{600}$ under T5 minus CSR under T1 ( $\mathrm{I}_{10}{ }^{600}$-CSR) vs. CRI are shown in Figure 2. It appears that the $\left(\mathrm{I}_{10}{ }^{600}-\mathrm{CSR}\right)$ values increase with the increase in CRI, and a line relation may exist, indicating that for cokes with high CRI from high volatile coals, a strong resistance capacity of strength deterioration appears at high temperatures.

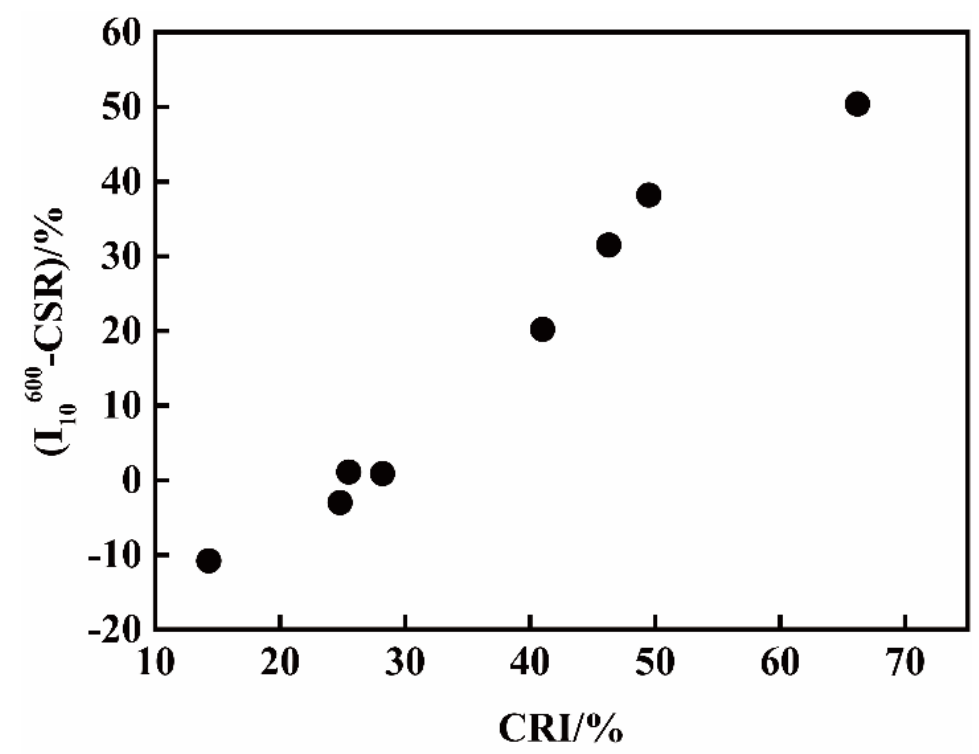

Figure 2. The $\left(\mathrm{I}_{10}{ }^{600}\right.$-CSR) vs. CRI of cokes.

\subsection{Morphology}

Tumbling strength is highly related to the walls and pores of coke. As mentioned above, the strength of pilot cokes had great differences under $\mathrm{T} 1$ and various changes occurred from T1 to T5, especially for cokes of C2 and C9 (77.5\% and 14.7\% under T1 and $66.7 \%$ and $65.1 \%$ under T5). The cokes of C2 and C9 were chosen as examples to study the microstructure morphologies. Their SEM images are shown in Figures 3 and 4 . It can be clearly seen that the degradation of coke surface tends to be serious with the increase of reaction temperature. The raw of C9 has more developed pore structure with uneven pore distribution than that of C2 (Figures 3a and $4 \mathrm{a}$ ), which may be conducive for gas diffusion, providing advantageous conditions for the solution loss reaction of coke. After being reacted at $1100{ }^{\circ} \mathrm{C}$, the edges and corners are obviously dissolved; meanwhile, the pore walls become thinner and a number of pores are connected, resulting in some larger pores (Figure $3 b$ or Figure $4 b$ ). This phenomenon for C9 is more obvious than that of C2, which may explain the very high CRI and low CSR of C9 (66.2\%/14.7\%). After reacted at $1300{ }^{\circ} \mathrm{C}$, in comparison, all the edges and corners almost disappeared. Simultaneously, the walls of the pores are thinner and the extension of the pore connections is deeper than that of raw coke and coke reacted at $1100{ }^{\circ} \mathrm{C}$ (Figure $3 \mathrm{c}$ or Figure $4 \mathrm{c}$ ).

\subsection{Carbon Structure}

Coke is created by the carbonization of coking coals and the average carbon crystal structure can be represented by a large number of small hexagonal crystallites in a turbostratic structure, along with small amounts of mineral matter as ash impurities [16]. The increase in structural order can be reflected in the increased narrowing of (002) peak by XRD characterization.

The XRD spectrums of C2 and C9 before reaction (raw samples) and after reaction at T1 and T5 are shown in Figure 5, respectively. For the (002) diffraction peaks of the 
two cokes, the intensity increases gradually and the shape sharpens with the increase in reaction temperature.

The carbon crystal structure parameters are listed in Table 4. The interplanar spacing (d(002)), crystallite size (La), and stack height of carbon crystallite (Lc) of coke are calculated using the classical Scherrer equation where $n$ is the number of graphitic planes in the stacking crystallite [14]. The value of $\left(\mathrm{n}_{\mathrm{T} 5}-\mathrm{n}_{\text {Raw }}\right) / \mathrm{nRaw}$ is the $n$ growth of coke under T5 compared to the original coke. It can be seen that the Lc values increase and the $d(002)$ values decrease with the increase of temperature for most cokes. The $n$ values increase as the temperature increases, which is especially apparent under $\mathrm{T} 5$ with the growth range from $49.23 \%$ to $95.18 \%$.
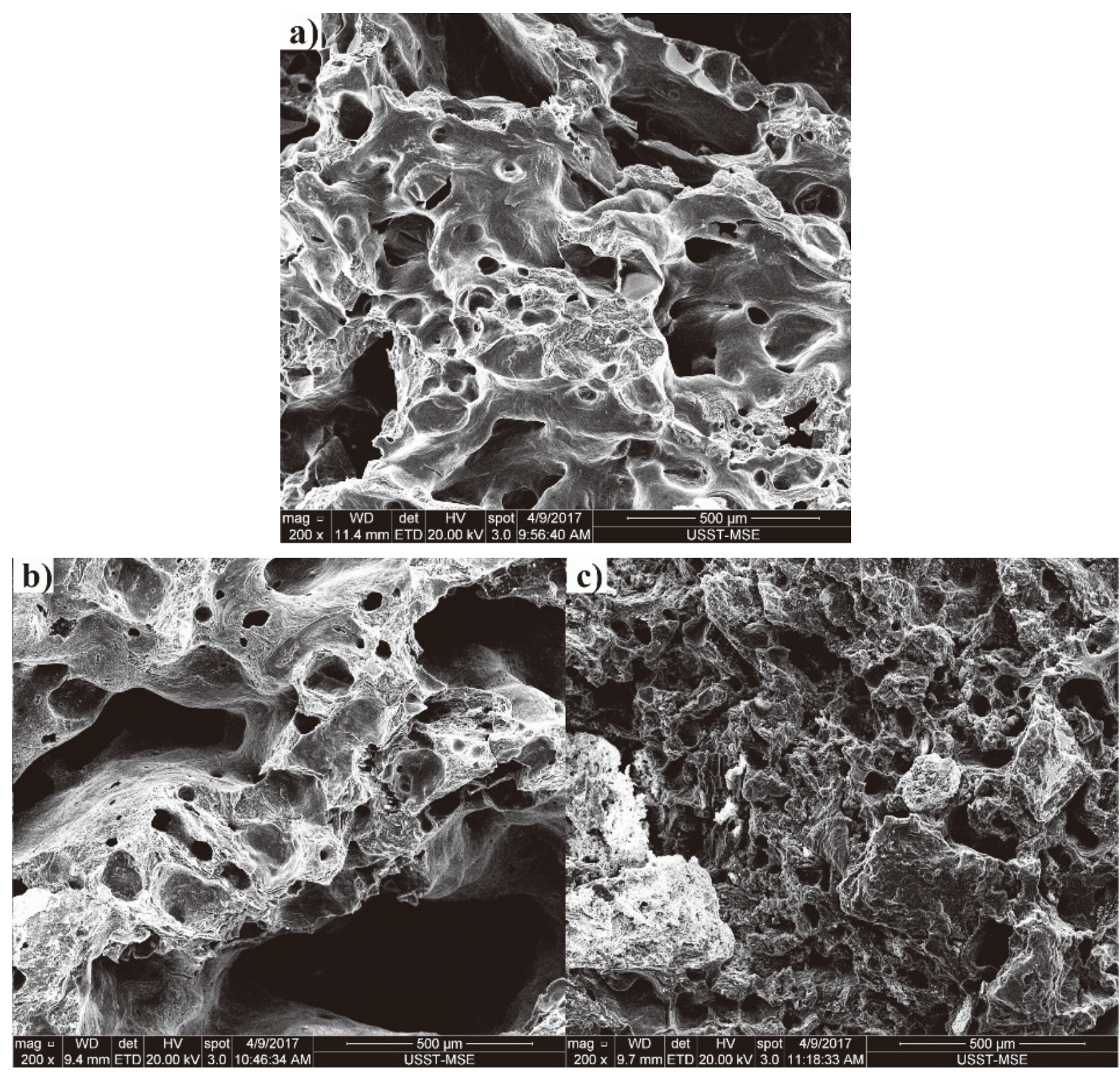

Figure 3. The SEM images of C2: (a) raw, (b) larger pores; (c) after reaction under T1 and T5. 


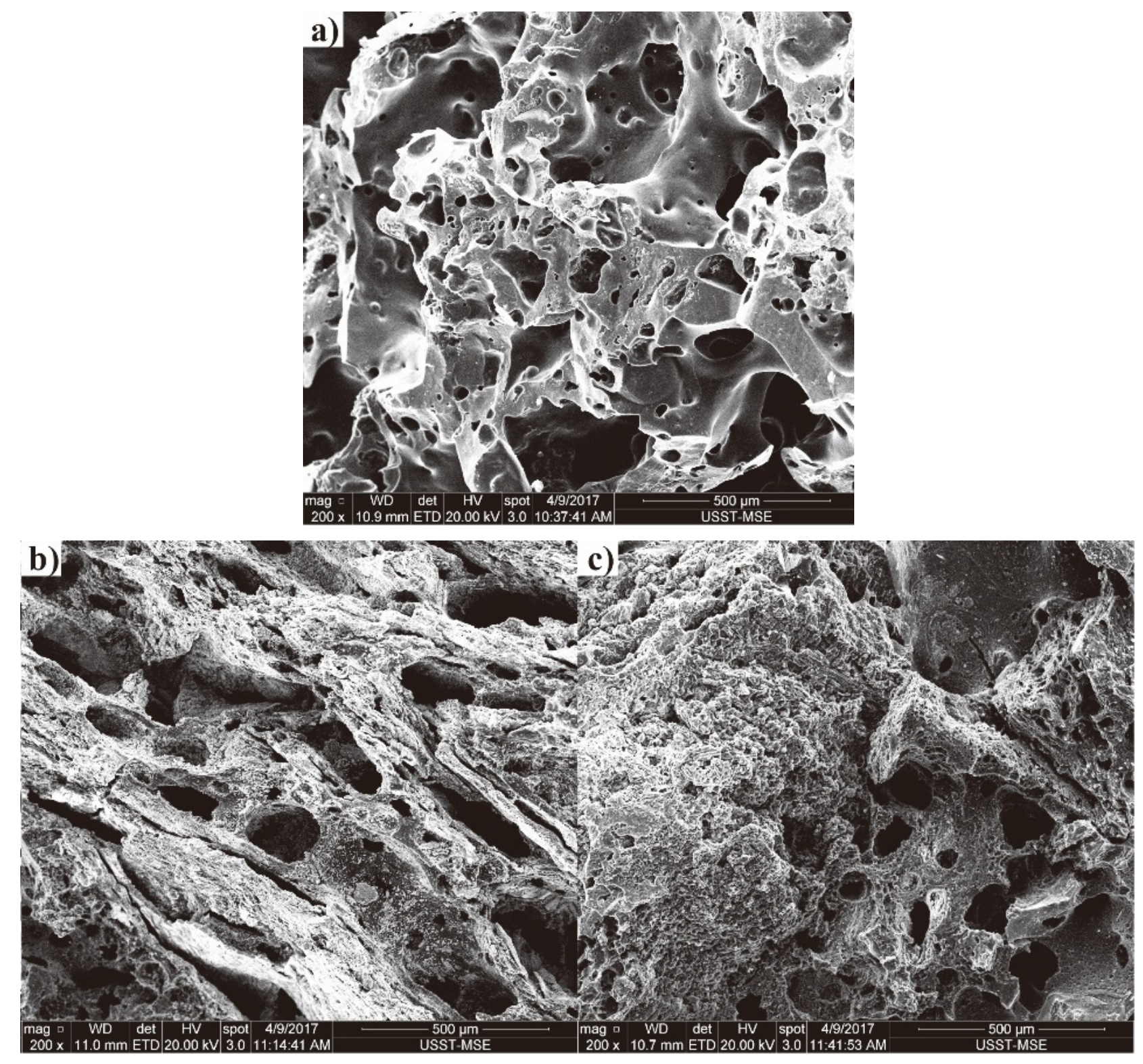

Figure 4. The SEM images of C9: (a) raw, (b) and (c) after reaction under T1 and T5.

(a)

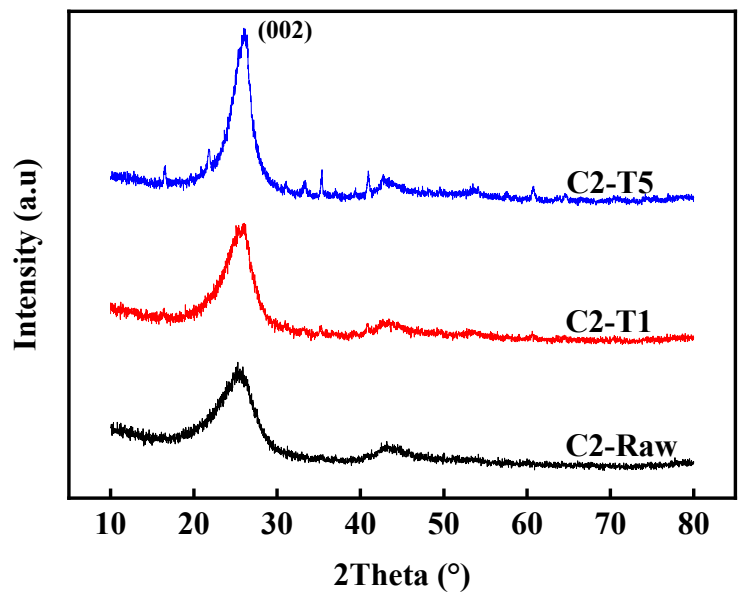

(b)

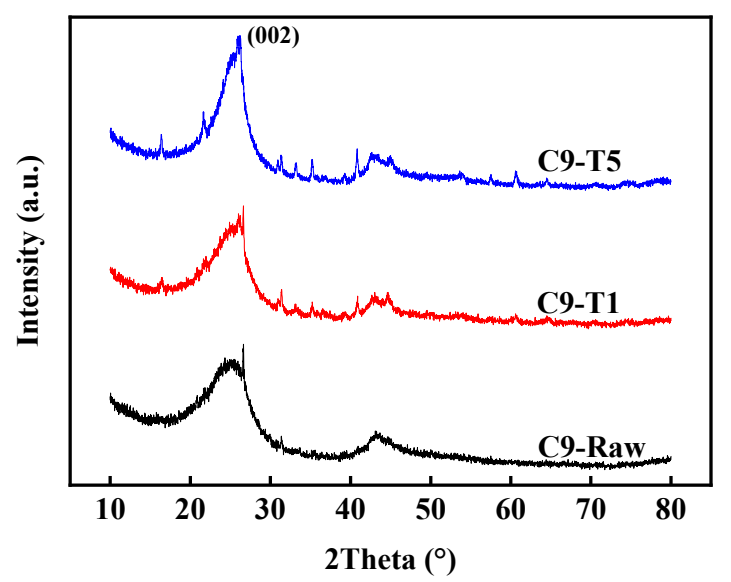

Figure 5. XRD diffraction spectrums for: (a) C2 and (b) C9. 
Table 4. The carbon crystal structure parameters of cokes.

\begin{tabular}{|c|c|c|c|c|c|c|c|}
\hline & Coke. & $\beta(002)\left({ }^{\circ}\right)$ & $\mathrm{d}(002)(\mathrm{nm})$ & $\operatorname{Lc}(\mathrm{nm})$ & La (nm) & $n(\mathrm{Lc} / \mathrm{d}(002))$ & $\left(\mathbf{n}_{\mathrm{T} 5}-\mathbf{n}_{\text {Raw }}\right) / \mathbf{n}_{\text {Raw }}(\%)$ \\
\hline \multirow{3}{*}{$\mathrm{C} 2$} & Raw & 4.694 & 0.3534 & 1.756 & 5.644 & 4.98 & \multirow{3}{*}{95.18} \\
\hline & $\mathrm{T} 1$ & 3.658 & 0.3438 & 2.256 & 6.054 & 6.57 & \\
\hline & T5 & 2.482 & 0.3423 & 3.326 & 7.610 & 9.72 & \\
\hline \multirow{3}{*}{$\mathrm{C} 3$} & Raw & 4.282 & 0.3387 & 1.929 & 8.611 & 5.70 & \multirow{3}{*}{70.88} \\
\hline & $\mathrm{T} 1$ & 3.316 & 0.3373 & 2.491 & 7.886 & 7.39 & \\
\hline & T5 & 2.519 & 0.3371 & 3.280 & 9.401 & 9.74 & \\
\hline \multirow{3}{*}{$\mathrm{C} 4$} & Raw & 4.382 & 0.3354 & 1.886 & 5.959 & 5.63 & \multirow{3}{*}{78.54} \\
\hline & $\mathrm{T} 1$ & 2.953 & 0.3362 & 2.799 & 7.994 & 8.33 & \\
\hline & $\mathrm{T} 5$ & 2.508 & 0.3439 & 3.290 & 8.228 & 9.57 & \\
\hline \multirow{3}{*}{ C5 } & Raw & 4.661 & 0.3521 & 1.769 & 6.041 & 5.02 & \multirow{3}{*}{61.75} \\
\hline & $\mathrm{T} 1$ & 3.798 & 0.3423 & 2.174 & 6.875 & 6.36 & \\
\hline & T5 & 2.958 & 0.3437 & 2.790 & 8.244 & 8.12 & \\
\hline \multirow{3}{*}{ C6 } & Raw & 4.482 & 0.3497 & 1.840 & 5.954 & 5.25 & \multirow{3}{*}{71.81} \\
\hline & $\mathrm{T} 1$ & 3.792 & 0.3469 & 2.175 & 9.086 & 6.26 & \\
\hline & T5 & 2.663 & 0.3441 & 3.099 & 9.402 & 9.02 & \\
\hline \multirow{3}{*}{ C7 } & Raw & 4.892 & 0.3496 & 1.686 & 8.146 & 4.82 & \multirow{3}{*}{60.63} \\
\hline & $\mathrm{T} 1$ & 3.440 & 0.3424 & 2.400 & 5.265 & 5.31 & \\
\hline & T5 & 2.783 & 0.3396 & 2.628 & 5.185 & 7.74 & \\
\hline \multirow{3}{*}{$\mathrm{C} 8$} & Raw & 5.052 & 0.3354 & 1.636 & 5.545 & 4.88 & \multirow{3}{*}{57.79} \\
\hline & $\mathrm{T} 1$ & 4.595 & 0.3407 & 1.797 & 4.898 & 5.26 & \\
\hline & $\mathrm{T} 5$ & 2.479 & 0.3396 & 2.620 & 5.000 & 7.70 & \\
\hline \multirow{3}{*}{ C9 } & Raw & 4.730 & 0.3362 & 1.747 & 3.698 & 5.20 & \multirow{3}{*}{49.23} \\
\hline & $\mathrm{T} 1$ & 4.002 & 0.3507 & 2.060 & 4.939 & 5.87 & \\
\hline & $\mathrm{T} 5$ & 3.133 & 0.3395 & 2.636 & 5.268 & 7.76 & \\
\hline
\end{tabular}

\subsection{Optical Texture}

Coke is a porous, fissured material which consists of pores, microfissures, and a solid carbon matrix with organic and inorganic inclusions. Recent research has shown that the properties of metallurgical coke depend on the relative proportion of isotropic carbon and inert, the size and shape of the anisotropic carbon units, the interface among textural components, porosity, and ash chemistry [16,17]. Many scientists also studied the consequences of anisotropy and the isotropic effect on coke quality and other technological parameters. They found that the reactivity of coke has a tendency to increase with the increase in isotropy. This indicates that a coke solution with carbon dioxide over a temperature of $800{ }^{\circ} \mathrm{C}$ shows selective attack, with the isotropic texture reacting more readily than the anisotropic texture [18,19].

According to vitrinite reflectance distribution, the optical texture of coke is mainly divided into isotropy (represented as $\Sigma$ ISO) and anisotropy (represented as $\Sigma$ OTI). The optical texture components of raw cokes are illustrated in Figure 6. It can be seen that C5, C7, C8, and C9 contain more $\Sigma$ ISO than other cokes, and their $\Sigma$ OTI is relatively less. On the contrary, C2, C3, C4, and C6 contain more $\Sigma$ OTI and less $\Sigma$ ISO.

The $\Sigma$ ISO components of raw coke after reaction under T1 and T5 are shown in Figure 7. It can be seen that the $\Sigma$ ISO composition of all the cokes after reaction under T1 is less than that of raw cokes and cokes reacted under T5, indicating that the isotropy of coke is easier to react with $\mathrm{CO}_{2}$ than the anisotropy under $\mathrm{T} 1$ at $1100{ }^{\circ} \mathrm{C}$ [20].

The reaction between carbon and $\mathrm{CO}_{2}$ mainly depends on activated carbons for adsorption and reaction, which are located at the edges and corners of coke. Isotropic carbon layers with random stacking have more micropores and activated carbon atoms, which makes it easier adsorb $\mathrm{CO}_{2}$ for reaction. The carbon layers of anisotropic structures with orderly stacking have fewer micropores and activated carbons and do not easily 
adsorb $\mathrm{CO}_{2}$ for reaction. It is for this reason that the isotropy of coke is easier to react with $\mathrm{CO}_{2}$ than the anisotropy at $1100{ }^{\circ} \mathrm{C}[21,22]$.

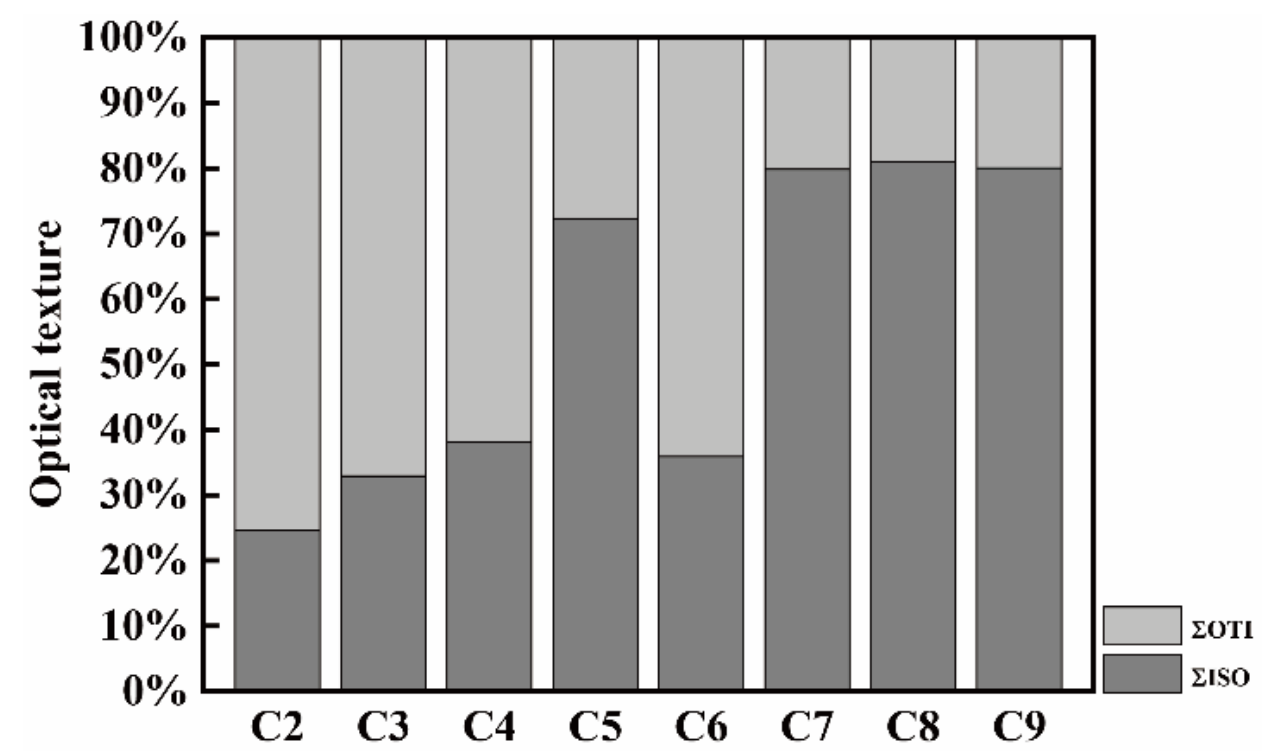

Figure 6. The optical texture of raw cokes.

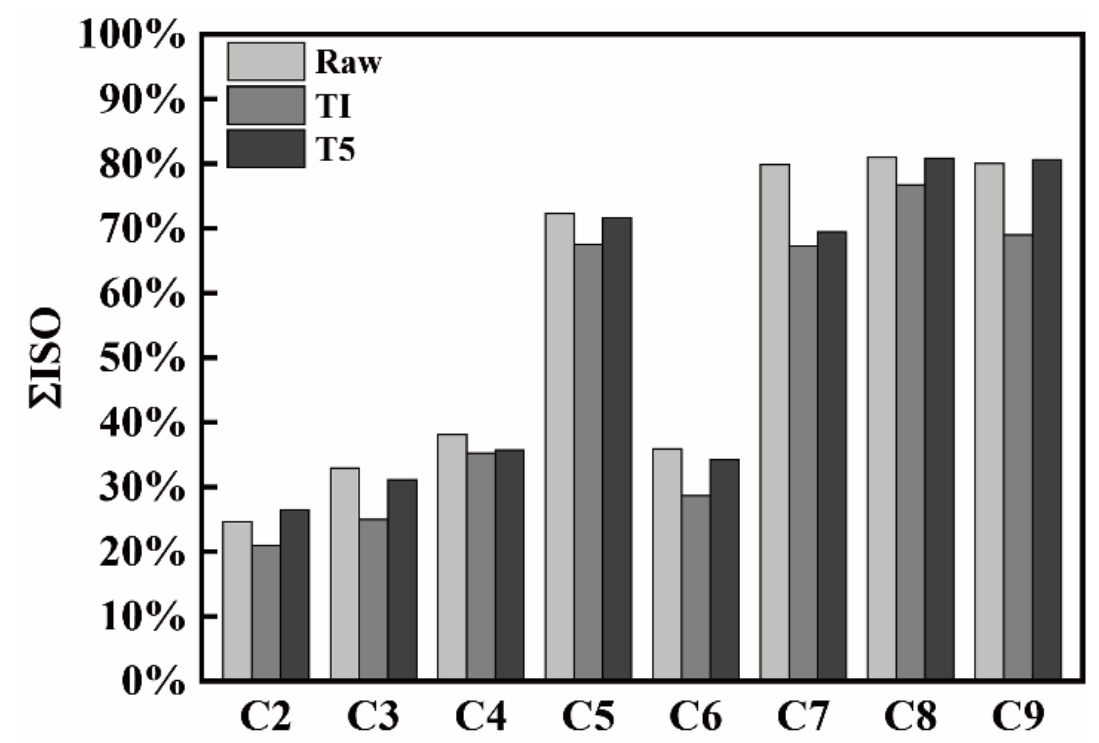

Figure 7. The $\Sigma$ ISO of cokes under different conditions.

The $\Sigma$ ISO ratio of cokes under $\mathrm{T} 5$ is larger than that of $\mathrm{T} 1$, indicating that the anisotropy reacts easier with $\mathrm{CO}_{2}$ than the isotropy at $1300{ }^{\circ} \mathrm{C}$ when compared with $1100{ }^{\circ} \mathrm{C}$. It can be considered that at high temperature, the carbon atoms in anisotropic structures of ordered stacking can easily react with $\mathrm{Na}, \mathrm{K}$ in coke to produce intercalation compounds, which would increase the distance and surface area of the reaction between the carbon layer, resulting in an easier reaction with $\mathrm{CO}_{2}[23]$.

The $\mathrm{I}_{10}{ }^{600}$ (under T1 and T5) and $\Sigma$ ISO components (raw coke) for all the cokes are displayed in Figure 8. It can be seen that the $\mathrm{I}_{10}{ }^{600}$ under $\mathrm{T} 5$ of C5, C7, C8, and C9 with high $\Sigma$ ISO values are far higher than their CSR. The $\mathrm{I}_{10}{ }^{600}$ under T5 of $\mathrm{C} 4$ and $\mathrm{C} 6$ with medium $\Sigma$ ISO are similar with their CSR, while the $\mathrm{I}_{10}{ }^{600}$ of $\mathrm{C} 2$ and $\mathrm{C} 3$ with low $\Sigma$ ISO values are lower than their CSR. These results illustrate that the $\Sigma$ ISO components of cokes have a serious effect on the $\mathrm{I}_{10}{ }^{600}$ at different temperatures. With the increase of temperature 
from $1100{ }^{\circ} \mathrm{C}$ to $1300{ }^{\circ} \mathrm{C}$, the $\Sigma \mathrm{ISO}$ components of cokes is first easier to react with $\mathrm{CO}_{2}$ at $1100{ }^{\circ} \mathrm{C}$, and then becomes harder at $1300^{\circ} \mathrm{C}$, as compared with $\Sigma$ OTI. It can be considered that at a high temperature, with the reacting of carbon atoms in anisotropic structures of ordered stacking with $\mathrm{Na}, \mathrm{K}$, some cracks in the carbon layer are created. The carbon atoms in unordered stacked isotropy are not so easy to react with $\mathrm{Na}, \mathrm{K}$ to produce intercalation compounds. Thus, the tumbling strength of isotropy is stronger than that of anisotropy at high reaction temperatures [23].

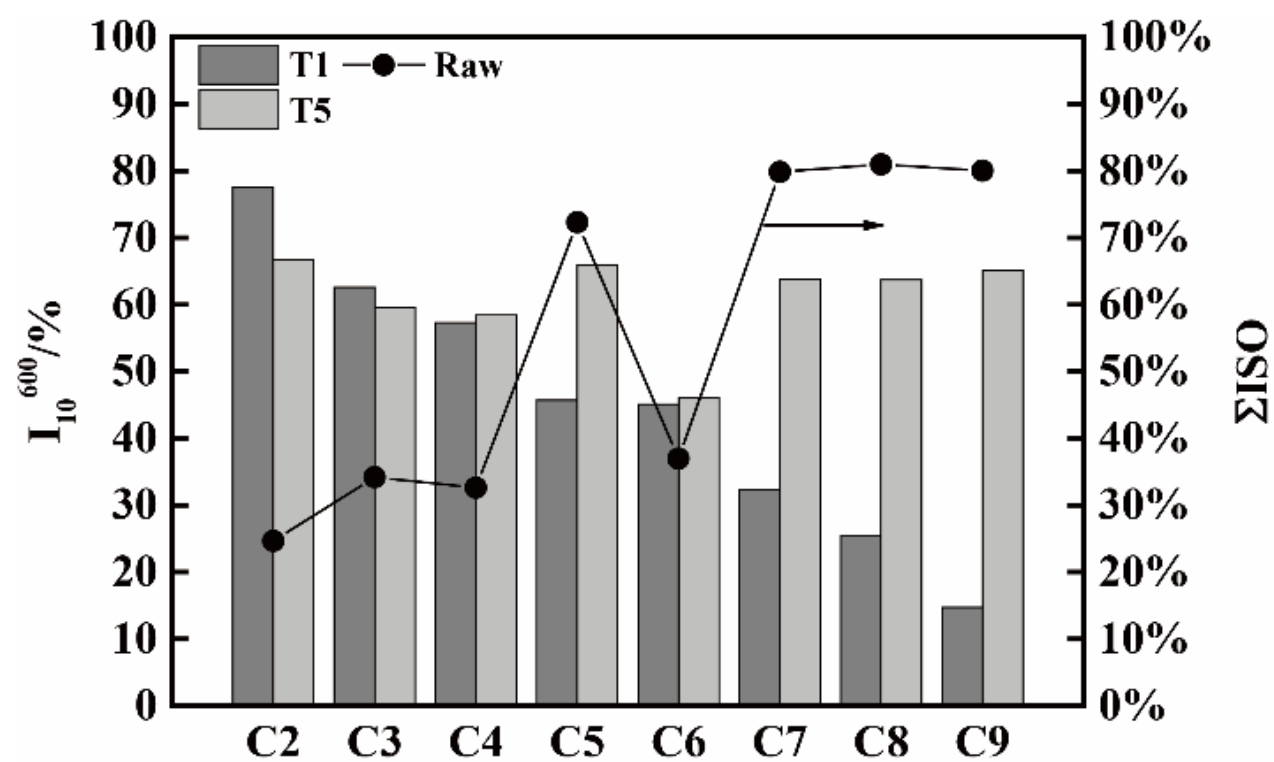

Figure 8. The $\mathrm{I}_{10}{ }^{600}$ (under T1 and T5) and $\Sigma \mathrm{ISO}$ (raw coke) values for all the cokes.

Figure 9 shows the $n$ and $\Sigma$ OTI (raw coke) values for all the cokes. It can be seen that the cokes of $\mathrm{C} 2, \mathrm{C} 3, \mathrm{C} 4$, and C6 containing more raw $\Sigma$ OTI components have a higher $n$ growth ratio under $\mathrm{T} 1$ and $\mathrm{T} 5$ as compared with $\mathrm{C} 5, \mathrm{C} 7, \mathrm{C} 8$, and $\mathrm{C} 9$ containing less $\Sigma \mathrm{OTI}$ components. It can be considered that the cokes which contain more anisotropy are easier to graphitize than other cokes with less anisotropy under high temperature [24].

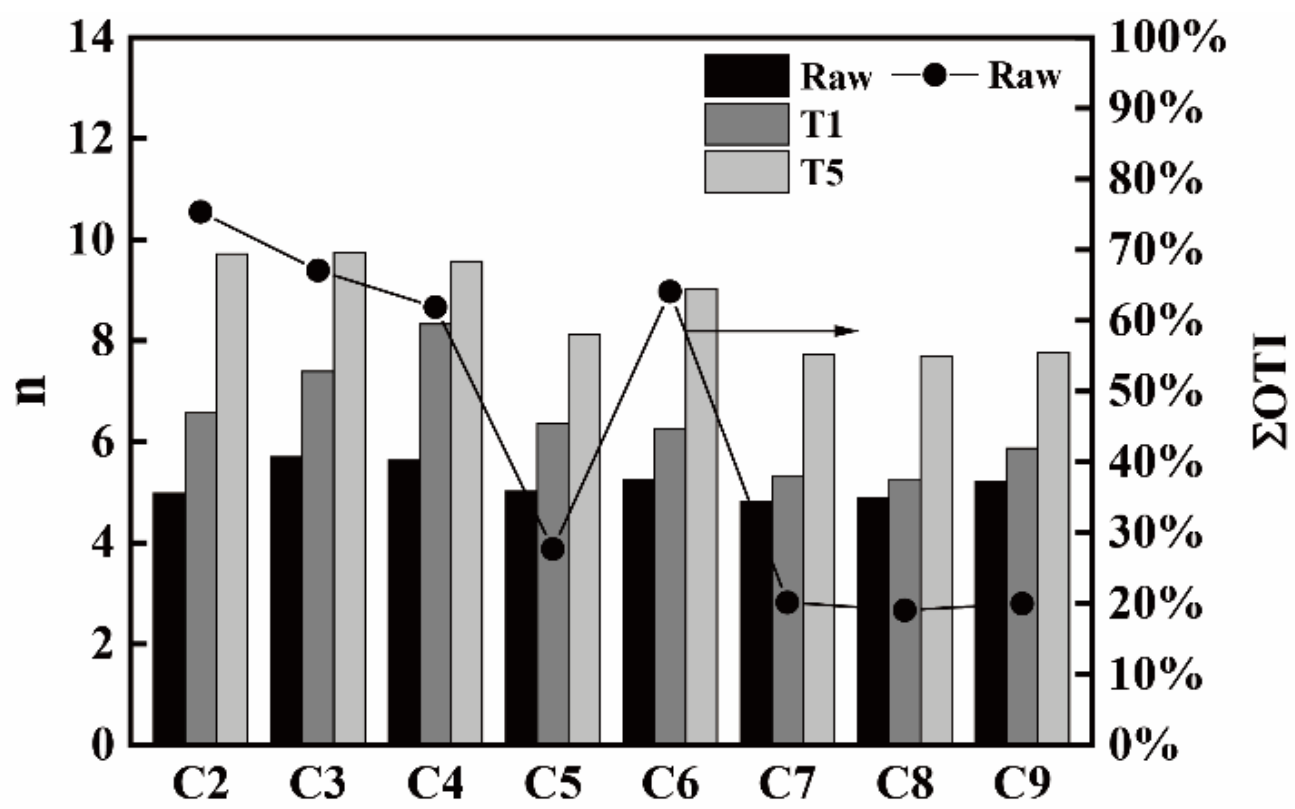

Figure 9. The $n$ and $\Sigma$ OTI (raw coke) values for all the cokes. 


\section{Conclusions}

The evaluating accuracy of CRI/CSR for coke in BFs has been disputed for many years. Many researchers have revised the CRI and CSR test conditions, including changing the pure $\mathrm{CO}_{2}$ to a mixture, raising the reaction temperature to high temperatures, controlling a constant weight loss of coke, etc. Most of the revised methods are either too complicated to be carried out or are time consuming. In this paper, a simple method of a $1300{ }^{\circ} \mathrm{C}$ and $0.5 \mathrm{~h}$ high temperature test is proposed to replace complicated simulation methods. Almost the same differences were found for evaluating coke quality between simulated and standard conditions. Temperature greatly affects the solution reaction and tumbling strength after coke reaction; especially at high temperatures up to $1300^{\circ} \mathrm{C}$, the reactivity of coke increases greatly. Under a high temperature of $1300{ }^{\circ} \mathrm{C}$ and a duration time of $0.5 \mathrm{~h}$, the changes of RI $/ \mathrm{I}_{10}{ }^{600}$ for cokes from different coals are very different compared with the standard test, and greatly related to the optical texture of cokes. Cokes with more isotropy increase in strength at high temperatures, and decrease with less isotropy. Similar to the methods proposed by other researchers, there is still a need for further experiments of more examples of different cokes. Furthermore, the accuracy of the method should be examined by the actual experience of production in the future.

Author Contributions: Conceptualization, G.Y.; Data curation, G.Y.; Formal analysis, X.W. (Xiaoqiang Wang); Funding acquisition, G.Y.; Investigation, X.W. (Xiaoqiang Wang); Methodology, T.S.; Project administration, G.Y.; Resources, G.Y.; Software, X.W. (Xinci Wu); Supervision, Y.X.; Validation, X.W. (Xinci Wu); Visualization, T.S.; Writing—original draft, G.Y.; Writing—review and editing, G.Y. All authors have read and agreed to the published version of the manuscript.

Funding: This work is financially supported by the National Natural Science Foundation of China (21875141, U1760119), the Science and Technology Commission of Shanghai Municipality (19DZ2271100), the Shanghai Scientific and Technological Innovation Project (19JC1410400), and the Innovation Program of Shanghai Municipal Education Commission (2019-01-07-00-07-E00015).

Institutional Review Board Statement: For studies not involving humans or animals.

Informed Consent Statement: For studies not involving humans.

Data Availability Statement: The data presented in this article are available on request from the corresponding author.

Conflicts of Interest: The authors declare no conflict of interest.

\section{References}

1. Grigore, M.; Sakurovs, R.; French, D.; Sahajwalla, V. Mineral reactions during coke gasification with carbon dioxide. Int. J. Coal Geol. 2008, 75, 213-224. [CrossRef]

2. Pusz, S.; Buszko, R. Reflectance parameters of cokes in relation to their reactivity index (CRI) and the strength after reaction (CSR), from coals of the Upper Silesian Coal Basin, Poland. Int. J. Coal Geol. 2012, 90-91, 43-49. [CrossRef]

3. Donskoi, E.; Poliakov, A.; Mahoney, M.R.; Scholes, O. Novel optical image analysis coke characterisation and its application to study of the relationships between coke structure, coke strength and parent coal composition. Fuel 2017, 208, 281-295. [CrossRef]

4. Flores, B.D.; Borrego, A.G.; Diez, M.A.; da Silva, G.L.; Zymla, V.; Vilela, A.C.; Osório, E. How coke optical texture became a relevant tool for understanding coal blending and coke quality. Fuel Process. Technol. 2017, 164, 13-23. [CrossRef]

5. Haapakangas, J.; Suopajärvi, H.; Iljana, M.; Kemppainen, A.; Mattila, O.; Heikkinen, E.P.; Samuelsson, C.; Fabritius, T. Coke reactivity in simulated blast furnace shaft conditions. Metall. Mater. Trans. B 2016, 47, 2357-2370. [CrossRef]

6. An, J.Y.; Seo, J.B.; Choi, J.H.; Lee, J.H.; Kim, H. Evaluation of characteristics of coke degradation after reaction in different conditions. ISIJ Int. 2016, 56, 226-232. [CrossRef]

7. Nomura, S.; Naito, M.; Yamaguchi, K. Post-reaction strength of catalyst-added highly reactive coke. ISIJ Int. 2007, 47, 831-839. [CrossRef]

8. Álvarez, R.; Díez, M.A.; Barriocanal, C.; Diaz-Faes, E.; Cimadevilla, J.L.G. An approach to blast furnace coke quality prediction. Fuel 2007, 86, 2159-2166. [CrossRef]

9. Gupta, S.; Dubikova, M.; French, D.; Sahajwalla, V. Effect of $\mathrm{CO}_{2}$ gasification on the transformations of coke minerals. Energy Fuels 2007, 21, 1052-1061. [CrossRef]

10. Sakurovs, R.; Burke, L. Influence of gas composition on the reactivity of cokes. Fuel Process. Technol. 2011, 92, 1220-1224. [CrossRef] 
11. Wang, Q.; Guo, R.; Zhao, X.-F.; Sun, J.-F.; Zhang, S.; Liu, W.-Z. A new testing and evaluating method of cokes with greatly varied CRI and CSR. Fuel 2016, 182, 879-885. [CrossRef]

12. Cheng, H.; Liang, Y.; Guo, R.; Sun, Z.; Wang, Q.; Wang, J. Effects of solution loss degree, reaction temperature, and high temperature heating on the thermal properties of metallurgical cokes. Fuel 2021, 283, 118936. [CrossRef]

13. Lundgren, M.; Sundqvist Ökvist, L.; Björkman, B. Coke reactivity under blast furnace conditions and in the CSR/CRI test. Steel Res. Int. 2009, 80, 396-401. [CrossRef]

14. Hilding, T.; Gupta, S.; Sahajwalla, V.; Björkman, B.; Wikström, J.O. Degradation behavior of a high CSR coke in an experimental blast furnace: Effect of carbon structure and alkali reactions. ISIJ Int. 2005, 45, 1041-1050. [CrossRef]

15. Zhang, W.; Shi, T.; Zhang, Q.; Cao, Y.; Qian, H.; Wu, X.; Li, J.; Zhang, Q.; Yang, G.; Yang, J. Coke texture, reactivity and tumbler strength after reaction under simulated blast furnace conditions. Fuel 2019, 251, 218-223. [CrossRef]

16. Li, K.; Khanna, R.; Zhang, J.; Liu, Z.; Sahajwalla, V.; Yang, T.; Kong, D. The evolution of structural order, microstructure and mineral matter of metallurgical coke in a blast furnace: A review. Fuel 2014, 133, 194-215. [CrossRef]

17. Gornostayev, S.S.; Heino, J.J.; Kokkonen, T.M.; Makkonen, H.T.; Huttunen, S.M.; Fabritius, T.M. Textural changes in metallurgical coke prepared with polyethylene. Int. J. Miner. Metall. Mater. 2014, 21, 969-973. [CrossRef]

18. Grigore, M.; Sakurovs, R.; French, D.; Sahajwalla, V. Properties and $\mathrm{CO}_{2}$ reactivity of the inert and reactive maceral-derived components in cokes. Int. J. Coal Geol. 2012, 98, 1-9. [CrossRef]

19. Piechaczek, M.; Mianowski, A.; Sobolewski, A. Reprint of "The original concept of description of the coke optical texture". Int. J. Coal Geol. 2015, 139, 184-190. [CrossRef]

20. Yang, M.; Cui, P. Coal influenced to microstructure during reaction of coke gasification. Coal Sci. Technol. 2005, 33, 42-44.

21. Geng, J.; Shen, H.; Liu, J. Current research situation and outlook of coke reactive capability. Yunnan Metall. 2009, $38,59-63$.

22. Wang, W.; Wang, J.; Xu, R.; Yu, Y.; Jin, Y.; Xue, Z. Influence mechanism of zinc on the solution loss reaction of coke used in blast furnace. Fuel Process. Technol. 2017, 159, 118-127. [CrossRef]

23. Zhou, S.; Zhao, J. Properties of Coking Coal and Quality of Coke for the Blast Furnace; Metallurgical Industry Press: Beijing, China, 2005.

24. Cancino-Trejo, F.; Sáenz Padilla, M.; López-Honorato, E.; Carvajal-Nunez, U.; Boshoven, J.; Somers, J. The effect of heat treatment on the microstructure and diffusion of silver in pyrolytic carbon coatings. Carbon 2016, 109, 542-551. [CrossRef] 